\title{
Inflammatory reaction induced by Floridosentis mugilis (Acanthocephala, Neoechinorhynchidae) in the intestine of Mugil liza
}

\author{
S. E. Plaul ${ }^{1}$, M. M. Montes ${ }^{2}$ (D) ${ }^{\text {, }}$, E. Topa ${ }^{2}$, S. R. Martorelli ${ }^{2}$, C. G. Barbeito \\ ${ }^{1}$ Facultad de Ciencias Veterinarias, Universidad Nacional de La Plata, ${ }^{2}$ Consejo Nacional del Investigaciones Científicas y Técnicas, Universidad Nacional de La \\ Plata \\ Keywords: Histopathology, mugilid fishes, acanthocephalans infections, eosinophilic granular cells \\ https://doi.org/10.48045/001c.31535
}

Bulletin of the European Association of Fish Pathologists

Vol. 41, Issue 3, 2021

\begin{abstract}
Lebranche mullet, Mugil liza, is an important economic resource and has been recommended for aquaculture in South America. Also, this is the only mullet that breeds in Argentina. In the course of our routine investigations on the parasitic fauna of fishes from brackish waters of Samborombón Bay, Buenos Aires province, an infection of acanthocephalan worms, identified as Floridosentis mugilis was observed in juvenile lebranche mullets. These parasites were attached deeply into the intestinal wall but without piercing it. In this study we analysed the intestinal damage that $F$. mugilis inflicts on their hosts through the evaluation of histological sections. In the pathological analysis we observed that these parasites cause a non-specific cellular response that leads to the degranulation of eosinophilic granular cells and, consequently, the formation of a fibrous core with oedema, vascular congestion, and lymphocytic infiltration.
\end{abstract}

\section{INTRODUCTION}

The family Mugilidae comprises one of the main resources in commercial estuary fisheries in all tropical, subtropical and temperate seas (Durand et al. 2012). Mugil liza Valenciennes, 1836, is distributed alongside the Atlantic coast of South America, from Argentina to Venezuela (Mai et al. 2014). This species is an important economic resource and has been recommended for aquaculture in South America (Godinho, da Silva Serralheiro, and Scorvo Filho 1988). Also, it is the only mullet that breeds in Argentina (González-Castro, Macchi, and Cousseau 2011). In winter, adults migrate to the pelagic coastal zone to spawn. Then, the larvae leave the marine waters and migrate to the estuarial waters of Samborombón Bay (Buenos Aires province, Argentina), where this species grows and develops until it reaches the adult stage (González Castro, Abachian, and Perrotta 2009). In the Samborombón Bay, the biggest mixohaline wetland of Argentina, the salinity gradient increases from north to south (Guerrero 1998). Also, in the north, the lotic system receives nutrients from the upper basin where extensive agricultural and livestock activities are carried out (Fernández Cirelli, Du Mortier, and Volpedo 2006), whereas in the south there is a higher oceanic influence (Schenone, Volpedo, and Cirelli 2007; Schenone 2008). 
During our routine investigations on the parasite fauna of fishes from brackish waters of Samborombón Bay, a total of 15 species of parasites were recorded in juvenile lebranche mullets (Montes and Martorelli 2015), but only one species of acanthocephalan worm was found attached in the intestinal wall. It was identified as Floridosentis mugilis (Machado-Filho, 1951). Suriano, Çuburu, and Labriola (2000) and Alarcos and Etchegoin (2010) previously reported this acanthocephalan in lebranche mullets from San Clemente del Tuyú and Mar Chiquita Lagoon (Buenos Aires province). However, the lesion produced by this parasite was not described. The pathological effect of acanthocephalan parasites in fishes was documented in Pomphorhynchus laevis (Müller, 1776) (Hine and Kennedy 1974; McDonough and Gleason 1981; Wanstall, Robotham, and Thomas 1986; Dezfuli 1991). These Acanthocephalans attach to the intestine of hosts by means of a spiny proboscis; the most significant feature of the damage is related to the depth of the penetration (Dezfuli et al. 2002, 2008). The mechanical destruction of the host's intestinal tissue is usually followed by host immune responses like proliferation of fibroblast and granular cell infiltration due to the irritation caused by the parasite at the perforation site (Scheelhaas 1980; Sanil et al. 2011). Therefore, the aim of the present study was to analyse the damage and the inflammatory reaction produced when F. muglis infects Mugil liza by means of a histological study of sections of intestine at the attachment site.

\section{MATERIALS AND METHODS}

\subsection{Samples}

A total of two hundred and eighty-one juvenile specimens of lebranche mullet were captured from two areas in the brackish waters of Samborombón Bay. Of these, 130 specimens $(15.25 \pm 0.61 \mathrm{~cm})$ were collected in the north of the bay (Salado River relief Channel 35 $50^{\prime} 10^{\prime \prime} S, 57^{\circ} 50^{\prime} 20^{\prime \prime} \mathrm{W}$ ) and 151 specimens $(18.55 \pm 0.63 \mathrm{~cm})$ in the south (Ajó River, Tapera de López $36^{\circ} 19^{\prime} 14^{\prime \prime} \mathrm{S}$, $\left.56^{\circ} 46^{\prime} 26^{\prime \prime} \mathrm{W}\right)$ (Figure 1). Fish were sampled in the spring and summer of 2015 and 2018 and collected from the coastal region using a modified Garlito/ Bituron fixed net (Colautti 1998) and a haul net (10 m length with $5 \mathrm{~mm}$ stretched mesh in the wings and $2.5 \mathrm{~mm}$ stretched mesh in the cod ends). The smallest sized fish were transported alive to the laboratory with water from the sample site with added oxygen and then kept in aquariums. The bigger sized fish were transported to the laboratory after being euthanised and examined for parasites in the field. The euthanasia of all specimens was performed quickly by decapitation following the guidelines of the American Fisheries Society (Nickum et al. 2004), and the intestine samples of the bigger individuals were rapidly removed and fixed by immersion in $10 \%$ buffered formalin for light microscopic studies. Upon post mortem, fish were measured (standard length, $\mathrm{cm}$ ) and fish that were between $4.7 \mathrm{~cm}$ and $27.15 \mathrm{~cm}$ in standard length were considered juveniles according by González-Castro, Macchi, and Cousseau (2011). 


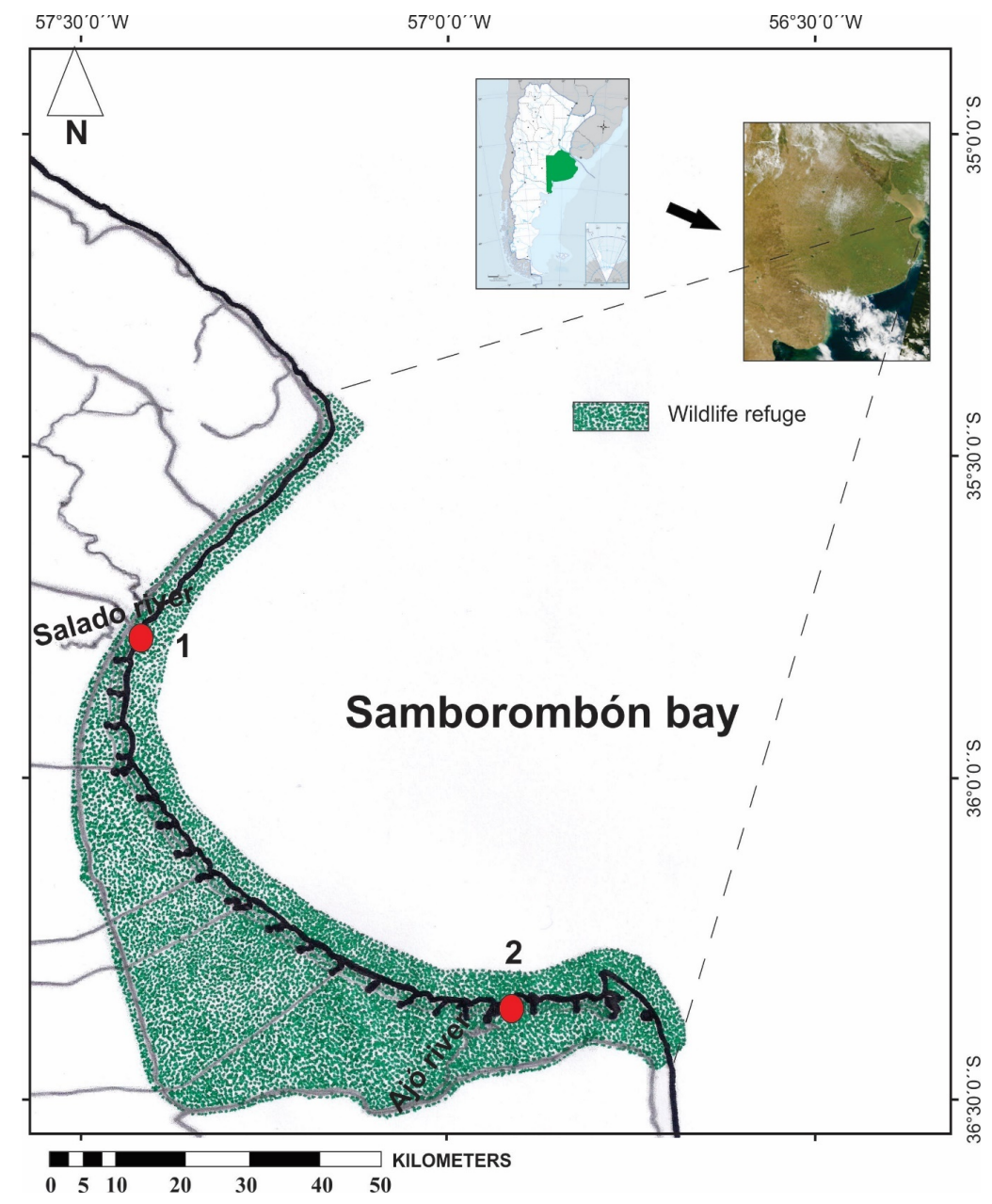

Figure 1. Map of the sampling site in the Samborombón Bay.

1. Salado River relief Channel and 2. Ajó River (Tapera de López).

\subsection{Parasite collection and identification}

Some of the smaller fish were sacrificed in the laboratory and the intestines were opened along their entire lengths and examined macroscopically. Parasites were collected with forceps and put into $0.85 \%$ physiological saline solution to allow for the proboscis to emerge and then stored in $70 \%$ ethanol for later identification. The prevalence and mean intensity of infection were calculated.

\subsection{Histological methods}

In order to evaluate the inflammatory reaction, sections of 10 infected intestines and 10 uninfected intestines were fixed in $10 \%$ neutral buffered formalin for $24 \mathrm{~h}$. The fixed samples were routinely processed and embedded in paraffin wax. Histological sections were obtained using a sledge microtome, prepared according to standard protocol, and then stained using the following techniques haematoxylin and eosin (H\&E), Masson's trichrome, the combined technique Alcian Blue $\mathrm{pH} 2.5$ with periodic acid-Schiff (AB/PAS) and Toluidine Blue with neutral red for counterstaining (TB/NR). The stained 


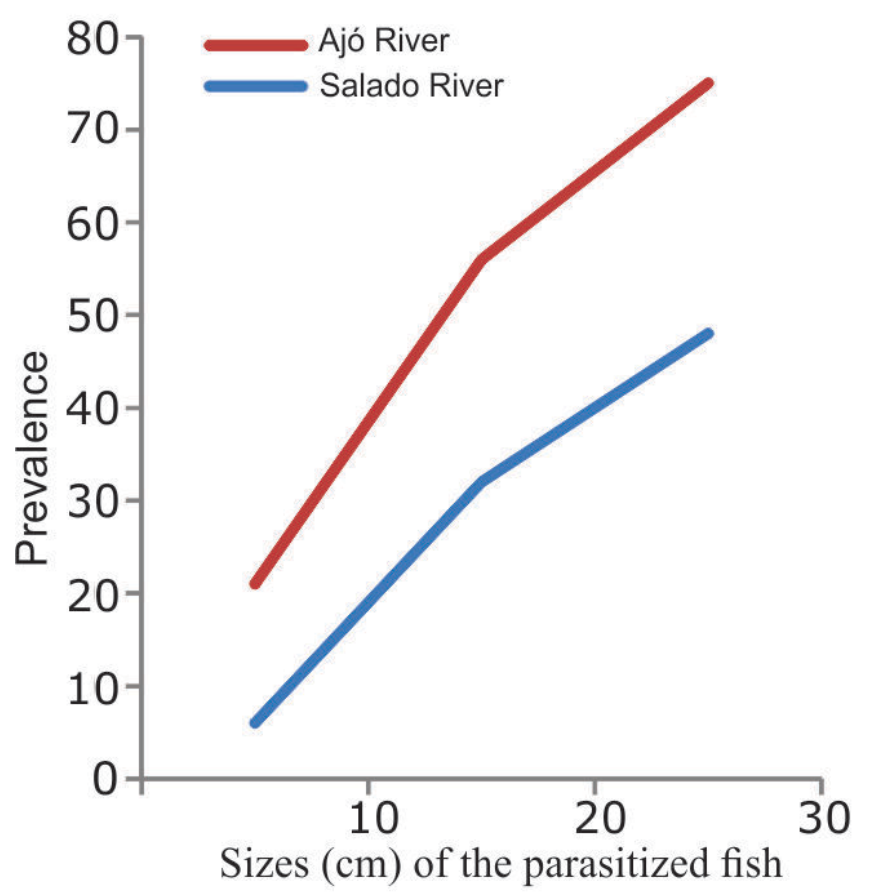

Figure 2. Relationship between the sizes of the parasitised fish and the prevalence.

slides were observed and photographed with an Olympus microscope DP 71 equipped with AmScope MU1000 10MP digital microscope camera (Tokyo, Japan).

\section{RESULTS}

The acanthocephalans distribution within the lebranche mullet gut was mainly in the cranial section of the intestine. The parasite was identified as $F$. mugilis based on morphological characteristics, as a cylindrical proboscis, the number of hooks rows and number of hooks (Suriano, Çuburu, and Labriola 2000).

The relationship between the size of the parasitised fish and the prevalence is shown in Figure 2. There was a positive correlation between the increase in fish size and the increase in prevalence. In the South of the bay, the prevalence was higher in all sizes, the lowest mean intensity found was 1.7 for the smallest sizes, and the highest mean intensity was 4 for the largest size.

Uninfected intestines of lebranche mullet showed normal microscopical structure with numerous villi (Figure 3a).

Infected intestines with $F$. mugilis showed the parasite proboscis penetrated deeply into the intestinal wall but without piercing it. Hypertrophy of lamina propria and tunica submucosa was observed at the site of attachment (Figure $\underline{3 b})$. In this site, the intestinal wall formed a fibrous core exposed directly to the lumen and the villi became shorter and more spaced as they approached the site of penetration (Figure 3b). Degeneration, erosion and detachment of the mucosal epithelium were sometimes observed as desquamation cells free 


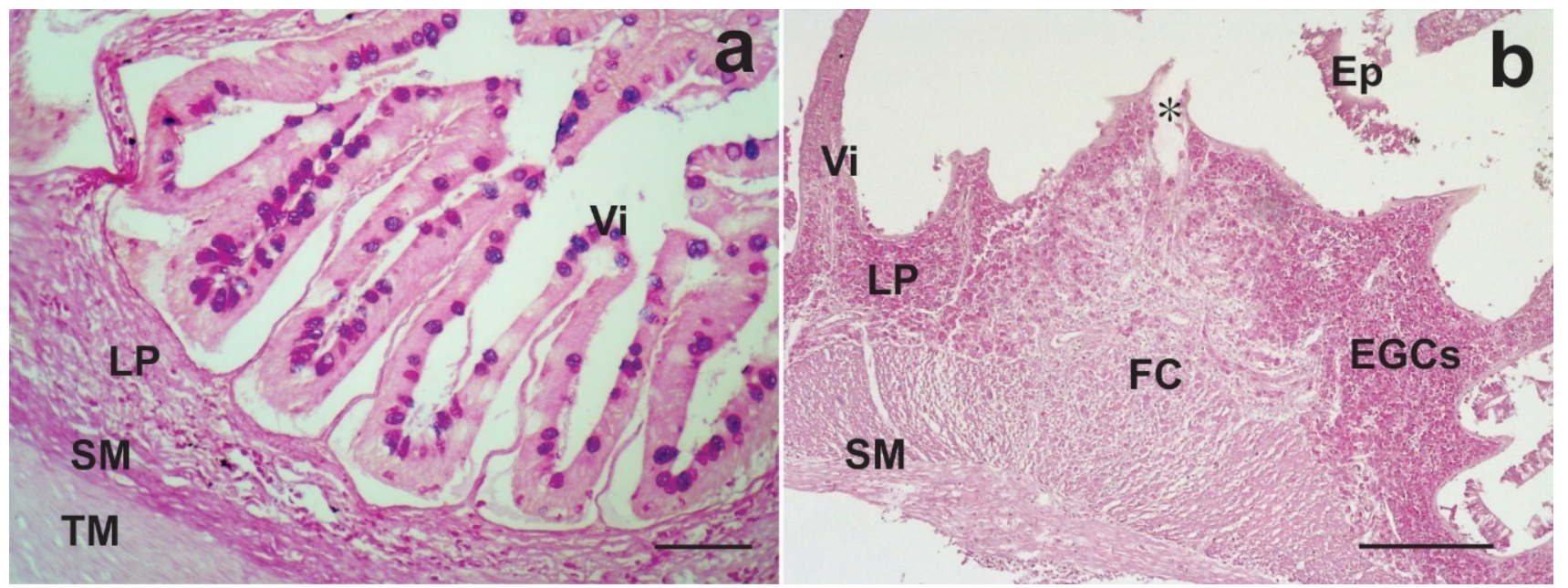

Figure 3. (a) Uninfected intestine with goblet cells positive to $A B / P A S$ stain. Scale bar $=50 \mu \mathrm{m}$. (b) Area where the parasite is attached, note the thickening of the intestinal wall, $\mathrm{AB} / \mathrm{PAS}$ stain. The asterisk shows the parasite attachment. Scale bar $=200 \mu \mathrm{m}$.

EGCs: eosinophilic granular cells, Ep: epithelium, FC: fibrous core, LP: lamina propria, TM: tunica muscularis, SM: tunica submucosa, Vi: villi.

in the lumen, (Figure 4a). Areas of the tunica mucosa devoid of the epithelial layer showed a thick fibrous layer which formed the innermost limit of the organ (Figure $4 \mathrm{a}, \mathrm{b})$. In the lamina propria, extensive cellular infiltration was observed, mainly composed of eosinophilic granular cells (EGCs) (Figure 4a, c). Infiltration of lymphocytes and oedematous dilated lymphatic vessels were also observed (Figure $4 \mathrm{~b}, \mathrm{c}$ ). In the lumen areas, where a simple columnar epithelium was recognised, a few mucous cells and EGCs among enterocytes were observed, in addition to a large lymphocyte infiltration (Figure $\underline{4 d}, \underline{5 a}$ ). A far from the parasite's attachment, accumulations of EGCs were observed only in the lamina propria and the tunica submucosa it was not hypertrophied (Figure 5b). Observations of serial sections stained with the Trichrome and $\mathrm{TB} / \mathrm{NR}$ techniques highlighted the fibrous core around the proboscis (Figure 5c) composed by collagen fibers in a disorderly arrangement (Figure $5 \mathrm{~d}$ ).

\section{DISCUSSION}

\section{Habitat and prevalence in the definitive host}

Species of Floridosentis Ward, 1953 (Acanthocephala) are common parasites of mugilid fishes which live in marine and brackish waters. They are widely distributed in the Atlantic and Pacific Oceans (Alarcos and Etchegoin 2010; Rosas-Valdez, Morrone, and García-Varela 2012; Montes and Martorelli 2015) and rarely parasitise other marine fish. In Argentina, the only mullet species with a permanent presence is $M$. liza (González-Castro, Macchi, and Cousseau 2011), This fish uses estuarine habitats as feeding growth and gonadal maturation sites (González Castro, Abachian, and Perrotta 2009; González Castro 2018). It is an amphibiotic species that enters the Samborombón Bay (López et al. 2001), wetland where artisanal and sport fishing are carried out. 


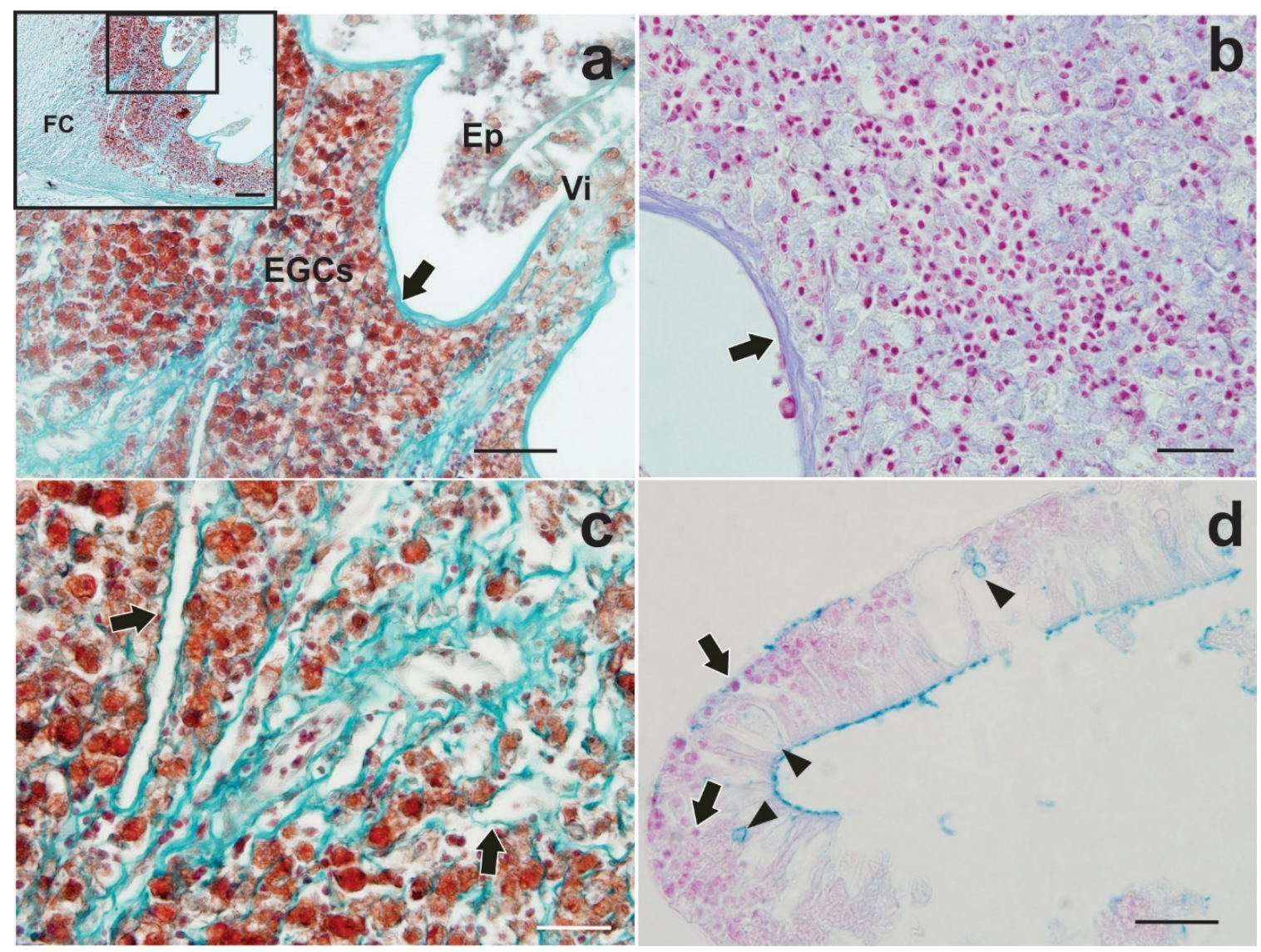

Figure 4. (a) A total erosive destruction of the epithelial layer, a thick fibrous layer limited the organ surface (black arrows). Epithelium is free in the lumen and the lamina propria shows an abundant EGCs infiltrate. Scale bar $=50 \mu \mathrm{m}$. Inset: Panoramic view of intestine wall in the attachment site. Scale bar $=100 \mu \mathrm{m}$. Masson's trichrome stain. (b) Detail of leukocytic infiltrate showing a great number of lymphocytes between EGCs, black arrow shows thick fibrous layer, TB/ NR stain. Scale bar $=20 \mu \mathrm{m}$. (c) Detail of leukocytic infiltrate showing a lot of EGCs and dilated lymphatic vessels (arrows), Masson's trichrome stain. Scale bar $=20 \mu \mathrm{m}$. (d) Epithelial detachment, note the low amount of mucous cells (arrowheads) and the great infiltrate of abundant lymphocytes (black arrows), AB/PAS stain. Scale bar $=20 \mu \mathrm{m}$.

EGCs: eosinophilic granular cells, Ep: Epithelium, FC: fibrous core, Vi: villi.

M. liza forms an important part of the diet and traditions of fishermen and their families. Besides this, it is an important species in the fishing industry (González Castro, Abachian, and Perrotta 2009; González Castro 2018).

Many species of acanthocephalans can cause lesions in the intestinal wall that lead to granuloma and subsequent fibrosis (Sanil et al. 2011). Although it has been recorded that acanthocephalans such as Pomphorbynchus spp. can perforate the intestinal wall of their hosts, F. mugilis penetrates deeply into the wall without piercing it, but affecting the tissues located at the insertion site. The severity of the injury, as in other parasitosis, depends on more than one factor, and is influenced by the intensity of infection, the site affected and often by environmental conditions (Kabata 1992; Plaul et al. 2013).

In both sites of our sampling regime, the prevalence of $F$. mugilis increased with increasing fish size, coinciding with the prevalence found by Alarcos and Etchegoin (2010) in Mar Chiquita lagoon. When comparing the prevalence in our two sampling sites from the Samborombón Bay, with a salinity gradient from north to south, we observed that in the south (Tapera de López) the 


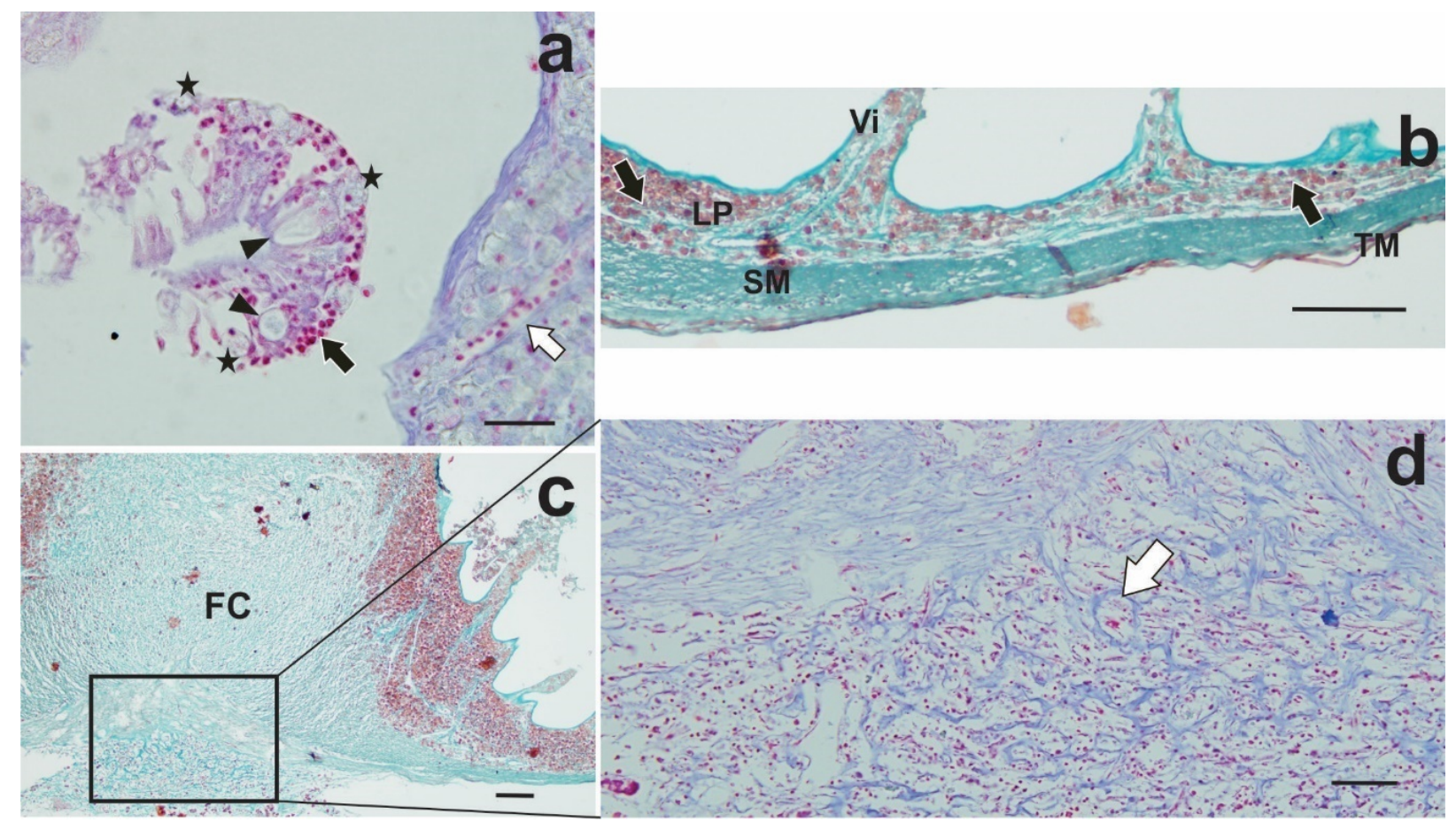

Figure 5. (a) Epithelial detachment shows mucous cells (arrowheads), a great infiltrate of abundant lymphocytes (black arrows) and some EGCs (stars) in the basal surface. The white arrow shows a dilated lymphatic vessel, TB/NR stain. Scale $\mathrm{bar}=20 \mu \mathrm{m}$. (b) Intestinal wall distant from the parasite's attachment, note an intense infiltrate of EGCs in the lamina propria (arrows), Masson's trichrome stain. Scale bar $=100 \mu \mathrm{m}$. (c) Panoramic view of intestine wall in the attachment site, Masson's trichrome stain. Scale bar $=100 \mu \mathrm{m}$. (d) Base of the fibrous core, the tunica muscularis and serosa are replaced by a network of collagen fibers (arrow) with intense lymphocytic infiltration, TB/NR stain. Scale bar $=50 \mu \mathrm{m}$.

FC: fibrous core, LP: lamina propria, TM: tunica muscularis, SM: tunica submucosa, Vi: villi.

prevalence was higher in all sizes. This coincides not only with the increase in the salinity of the environment, but also with the lack of pollutants (lead, zinc, copper and arsenic) and nutrients such as phosphorous and nitrogen, according to studies carried out by Schenone (2008).

The life cycle of Floridosentis sp. is unknown, but other neochinorhynchids include intermediate small crustaceans (amphipods, copepods and ostracods) as intermediate hosts. When the intermediate hosts are ingested by the fish (definitive host), the larvae excyst, attach to the intestinal wall and becomes sexually mature (Kennedy 2006; Rosas-Valdez, Morrone, and García-Varela 2012). The feeding studies of juveniles and subadults of $M$. liza within the Argentine territory recorded by Jerez and Christiansen (1987), Acha (1990) and Thompson et al. (2015) indicated the presence of benthic diatoms, dinoflagellates and metazoans, mainly copepods and amphipods in the stomach content. No changes in the diet were observed with the body size. This data led us to suggest copepods and amphipods as intermediate hosts for F. mugilis. These crustaceans must be more abundant in the waters of the southern area of the bay due to the conditions of $\mathrm{pH}$, oxygen concentration, the greater oceanic influence, and the absence of agricultural and livestock activity. 
Floridosentis mugilis was found in the cranial section of the intestine, while the digeneans occupied the rest of the intestine. According to Jmii Chine, Ben Saad, and Gargouri (2020) its spatial distribution pattern might be related to the competition between the helminth species present in the same organ, such as digeneans, in which every species segregates according to their habitat preference.

The proboscis of acanthocephalans, which have a large number of abrasive hooks, is the main organ responsible for damage of the host's intestine (Chaicharn and Bullock 1967). In the present report, the reaction observed in the intestinal wall showed hypertrophy of the lamina propria and the tunica submucosa with widespread hyperplasia of EGCs in the lamina propria. In Neoechinorhynchus sp. (Rudolphi, 1819) Jmii Chine, Ben Saad, and Gargouri (2020) also observed an increase in the amount of EGCs in the lamina propria but without occupying the entire layer. Dezfuli et al. (2011), Rieger and Barreda (2011) and Prykhozhij and Berman (2014) registered the presence of EGCs in response to the infection by parasites, associated with non-specific cellular immunity. The degranulation of EGCs with the release of histamine is one of the first steps during the inflammatory response (Dezfuli et al. 2008). Histamine stimulates the migration and proliferation of fibroblasts, oedema, and the formation of the so-called fibrous core. In the currently described infection by $F$. mugilis, although the parasite did not pierce the intestinal wall, the penetration was deep and capable to induce a rather severe, possibly irreversible damage at the attachments points.

In conclusion, this acanthocephalan worm does not pierce the intestinal wall, but it causes a non-specific cellular response with an abundant infiltrate of EGCs and lymphocytes. The degranulation of EGCs leads the formation of a fibrous core with oedema and intense vascular congestion. Although the mean intensity observed was low in wild fish, the focal effects described here cause severe and probably irreversible damage to the affected portion of the intestine. In addition, it should be considered that other parasites are often found sharing the same organ, further complicating the clinical picture, causing the thinning of the fish and therefore a lower economic value of its meat. 


\section{REFERENCES}

Acha, E.M. 1990. "Estudio Anatómico-Ecológico de La Lisa (Mugil Liza) Durante Su Primer Año de Vida." Frente Maritimo 7 ( $\sec$ A): 37-43.

Alarcos, Ana Julia, and Jorge Alejandro Etchegoin. 2010. "Parasite Assemblages of EstuarineDependent Marine Fishes from Mar Chiquita Coastal Lagoon (Buenos Aires Province, Argentina).” Parasitology Research 107 (5): 1083-91. https://doi.org/10.1007/s00436-010-1974-z.

Chaicharn, Aimorn, and Wilbur L. Bullock. 1967. "The Histopathology of Acanthocephalan Infections in Suckers with Observations on the Intestinal Histology of Two Species of Catostomid Fishes." Acta Zoologica 48 (1-2): 19-42. https://doi.org/10.1111/j.1463-6395.1967.tb00130.x.

Colautti, D.C. 1998. "Sobre la utilización de trampas para peces en las lagunas pampásicas." Revista de Ictiología 6: 17-23.

Dezfuli, B.S. 1991. "Histopathology in Leuciscus Cephalus (Pisces: Cyprinidae) Resulting from Infection with Pomphorbynchus Laevis (Acanthocephala).” Parassitologia 33: 137-45.

Dezfuli, B.S., L. Giari, E. Simoni, Bosi G, and M. Manera. 2002. "Histopathology, Immunohistochemistry and Ultrastructure of the Intestine of Leuciscus Cephalus (L.) Naturally Infected with Pomphorbynchus Laevis (Acanthocephala)." Journal of Fish Diseases 25: 7-14.

Dezfuli, B.S., L. Giari, S. Squerzanti, A. Lui, M. Lorenzoni, S. Sakalli, and A.P. Shinn. 2011. "Histological Damage and Inflammatory Response Elicited by Monobothrium Wageneri (Cestoda) in the Intestine of Tinca (Cyprinidae).” Parasites E Vectors 4: 225.

Dezfuli, B.S., G. Giovinazzo, A. Lui, and L. Giari. 2008. "Inflammatory Response to Dentitruncus Truttae (Acanthocephala) in the Intestine of Brown Trout." Fish E'Shellfish Immunology 24 (6): 726-33. https://doi.org/10.1016/j.fsi.2007.11.013.

Durand, J.-D., K.-N. Shen, W.-J. Chen, B.W. Jamandre, H. Blel, K. Diop, M. Nirchio, et al. 2012. "Systematics of the Grey Mullets (Teleostei: Mugiliformes: Mugilidae): Molecular Phylogenetic Evidence Challenges Two Centuries of Morphology-Based Taxonomy.” In Molecular Phylogenetics and Evolution, 64.1:73-92.

Fernández Cirelli, A., C. Du Mortier, and A.V. Volpedo. 2006. "Influencia de las actividades agropecuarias en los procesos de eutrofización en la Cuenca Baja del Río Salado (Provincia de Buenos Aires, Argentina)." In Eutrophication in South America: causes, consequences and technologies for management and control, edited by José Galizia Tundisi, Takako Matsumura Tundisi, and Corina Sidagis Galli, 17-34.

Godinho, H.M., P.C. da Silva Serralheiro, and J.D. Scorvo Filho. 1988. "Revisão e discussão de trabalhos sobre as espécies do gênero Mugil (Teleostei, Perciformes, Mugilidae) da costa brasileira (Lat. $3^{\circ}$ S-33ㅇ)." Boletim do Instituto de Pesca 15: 67-80.

González Castro, M. 2018. “Las Lisas de Argentina.” In Peces y Pesca Deportiva Argentina. Mary Patagonia. https://www.labibliotecadelnaturalista.com/productos/peces-y-pesca-deportiva-arg.

González Castro, M., V. Abachian, and R. G. Perrotta. 2009. "Age and Growth of the Striped Mullet, Mugil Platanus (Actinopterygii, Mugilidae), in a Southwestern Atlantic Coastal Lagoon (37 $\left.32^{\prime} \mathrm{S}-57^{\circ} 19^{\prime} \mathrm{W}\right)$ : A Proposal for a Life-History Model." Journal of Applied Ichthyology 25 (1): 61-66. https://doi.org/10.1111/j.1439-0426.2008.01170.x.

González-Castro, M., G. J. Macchi, and M. B. Cousseau. 2011. "Studies on Reproduction of the Mullet Mugil Platanus Günther, 1880 (Actinopterygii, Mugilidae) from the Mar Chiquita Coastal Lagoon, Argentina: Similarities and Differences with Related Species." Italian Journal of Zoology 78 (3): 343-53. https://doi.org/10.1080/11250003.2010.549154.

Guerrero, R.A. 1998. “Oceanografia física del estuario del Rio de la Plata y el sistema costero de El Rincón.” INIDEP Informe Técnico 21: 29-54. 
Hine, P. M., and C. R. Kennedy. 1974. "Observations on the Distribution, Specificity and Pathogenicity of the Acanthocephalan Pomphorhynchus Laevis (Müller)." Journal of Fish Biology 6 (4): 521-35. https://doi.org/10.1111/j.1095-8649.1974.tb04569.x.

Jerez, B., and H.E. Christiansen. 1987. “Estudio anatómico e histológico del sistema digestivo de la lisa (Mugil liza) de la laguna Mar Chiquita, y breve comentario sobre su alimentación.” Publicaciones de la Comisión Técnica Mixta del Frente Maritimo 3: 79-91.

Jmii Chine, H., C. Ben Saad, and L. Gargouri. 2020. "Seasonality and Histopathology of Neoechinorbynchus Sp. (Rudolphi, 1819) (Acanthocephala: Neoechinorhynchidae) in the Flathead Grey Mullet Mugil Cephalus (Linnaeus, 1758) from Ichkeul Lagoon in Northern Tunisia.” Bulletin of the European Association of Fish Pathologists 40 (3): 95-105.

Kabata, Z. 1992. "Copepods Parasitic on Fishes: Keys and Notes for Identification of the Species." In Synopses of the British Fauna (New Series) $N^{\circ} 47$, edited by D.M. Kermack, R.S.K. Barnes, and J.H. Crothers, 264.

Kennedy, C. R. 2006. Ecology of the Acanthocephala. New York, New York: Cambridge University Press. https://doi.org/10.1017/cbo9780511541902.

López, H.L., C.R. Baigún, J.M. Iwaszkiw, Delfino RL, and O.H. Padin. 2001. "La cuenca del Salado: Uso y posibilidades de sus recursos pesqueros.” Editorial de la Universidad de La Plata.

Mai, Ana C.G., Carolina I. Miño, Luis F.F. Marins, Cassiano Monteiro-Neto, Laura Miranda, Paulo R. Schwingel, Valéria M. Lemos, Mariano Gonzalez-Castro, Jorge P. Castello, and João P. Vieira. 2014. "Microsatellite Variation and Genetic Structuring in Mugil Liza (Teleostei: Mugilidae) Populations from Argentina and Brazil.” Estuarine, Coastal and Shelf Science 149 (August): 80-86. https://doi.org/10.1016/j.ecss.2014.07.013.

McDonough, J. Melissa, and Larry N. Gleason. 1981. "Histopathology in the Rainbow Darter, Etheostoma Caeruleum, Resulting from Infections with the Acanthocephalans, Pomphorbynchus Bulbocolli and Acanthocephalus Dirus." Journal of Parasitology 67 (3): 403. https://doi.org/10.2307/ 3280564.

Montes, Martin M., and Sergio R. Martorelli. 2015. "An Ecological and Comparative Analysis of Parasites in Juvenile Mugil Liza (Pisces, Mugilidae) from Two Sites in Samborombón Bay, Argentina." Iheringia, Série Zoologia 105 (4): 403-10. https://doi.org/10.1590/ 1678-476620151054403410.

Nickum, J.G., H.L. Bart, P.R. Bowser, I.E. Greer, C. Hubbs, J.A. Jenkins, J.R. MacMillan, et al. 2004. Guidelines for the Use of Fishes in Research. Bethesda, MD: American Fisheries Society.

Plaul, S.E., M.M. Montes, C.G. Barbeito, and S. Martorelli. 2013. "Morphological Aspects and Histological Effects of the Attachment Organ of Parabrachiella Sp. (Copepoda: Lernaeopodidae) on the Grey Mullet Mugil Liza Valenciennes, 1836." Journal of Fish Diseases 36 (10): 853-59.

Prykhozhij, Sergey V., and Jason N. Berman. 2014. "The Progress and Promise of Zebrafish as a Model to Study Mast Cells.” Developmental E̊ Comparative Immunology 46 (1): 74-83. https://doi.org/10.1016/j.dci.2014.01.023.

Rieger, Aja M., and Daniel R. Barreda. 2011. "Antimicrobial Mechanisms of Fish Leukocytes.” Developmental $\Xi^{\circ}$ Comparative Immunology 35 (12): 1238-45. https://doi.org/10.1016/ j.dci.2011.03.009.

Rosas-Valdez, Rogelio, Juan J. Morrone, and Martín García-Varela. 2012. "Molecular Phylogenetics of Floridosentis Ward, 1953 (Acanthocephala: Neoechinorhynchidae) Parasites of Mullets (Osteichthyes) from Mexico, Using 28 S RDNA Sequences." Journal of Parasitology 98 (4): 855-62. https://doi.org/10.1645/ge-2963.1. 
Sanil, N.K., P.K. Asokan, J. Lijo, and K.K. Vijayan. 2011. "Pathological Manifestations of the Acanthocephalan Parasite, Tenuiproboscis Sp. in the Mangrove Red Snapper (Lutjanus Argentimaculatus) (Forsskål, 1775), a Candidate Species for Aquaculture from Southern India” 310: 259-66.

Scheelhaas, D.P. 1980. "Comparative Histopathology of Acanthocephan Infections in Some Freshwater Fishes.” M. Sc. Thesis, University of North Dakota.

Schenone, Nahuel. 2008. "Estado trofico y variación estacional de nutrientes en los ríos y canales del humedal mixo-halino de Bahia Samborombón (Argentina)." Limnetica 27 (1): 143-50.

Schenone, Nahuel, Alejandra Vanina Volpedo, and Alicia F. Cirelli. 2007. "Trace Metal Contents in Water and Sediments in Samborombón Bay Wetland, Argentina." Wetlands Ecology and Management 15 (4): 303-10. https://doi.org/10.1007/s11273-006-9030-6.

Suriano, D.M., M.L. Çuburu, and J.B. Labriola. 2000. "Floridosentis mugilis (Machado Filho, 1951) (Acanthocephala: Neoechinorhynchidae) from Mugil platanus Gunther, 1880 (Mugiliformes: Mugilidae) in San Clemente del Tuyu, Buenos Aires province, atlantic coast, Argentina." Research and Reviews in Parasitology 60 (3-4): 107-12.

Thompson, Gustavo, Roberta Callico Fortunato, Ignacio Chiesa, and Alejandra Volpedo. 2015. "Trophic Ecology of Mugil Liza at the Southern Limit of Its Distribution (Buenos Aires, Argentina).” Brazilian Journal of Oceanography 63 (3): 271-78. https://doi.org/10.1590/ $\underline{\text { s1679-87592015087106303. }}$

Wanstall, S.T., P.W.J. Robotham, and J.S. Thomas. 1986. "Pathological changes induced by Pomphorbynchus laevis Müller (Acanthocephala) in the gut of rainbow trout, Salmo gairdneri Richardson.” Zeitschrift für Parasitenkunde 72: 105-14. 